\title{
Leadership and Institutional Reform: Engineering Macroeconomic Policy Change in Australia
}

\author{
SHAUN GOLDFINCH* AND PAUL ‘t HART**
}

This article seeks to enhance the actor perspective on major policy reforms. It builds upon the literature on "policy entrepreneurs" and addresses its explanatory vagueness by specifying five hypotheses outlining the actions that proponents of major policy change need to take in order to be effective in forging departures from existing, path-dependent policies and to overcome entrenched opposition to reforms. These hypotheses on "reformist political leadership" (after Blondel) are applied to the four attempts to reform key aspects of macroeconomic policy in Australia under the first two Labor governments led by Robert J. Hawke.

What role does political leadership play in engineering policy change? We investigate this by examining the remarkable economic liberalization of Australia during the 1980s. During the life of the Labor government, from 1983 to 1996, the Australian economy moved to become one of the more open economies in the Organisation for Economic Cooperation and Development (OECD). Changes included the floating of the exchange rate and extensive financial liberalization, a move towards fiscal discipline and macroeconomic stability, extensive microeconomic reform, trade liberalization, widescale privatization, and a gradual liberalization of the labor market through an incomes policy known as the Accord. To try to understand this period of change and the role of leadership in this process, we develop a theory of reformist political leadership that highlights crisis recognition and crisis management as a crucial vehicle for effecting reforms. Drawing on ninety-three interviews carried out with policy elites and influentials for a larger study of economic policy-making in Australia (Goldfinch 2000) as well as other primary and secondary literature, we apply the theory to four critical episodes in Australian financial and macroeconomic policy. We then highlight its ability to explain successful and unsuccessful attempts at reforming the economy.

The remarkable changes in Australia are particularly interesting because a large body of literature explores why policies do not change. The ascent-or, more appropriately, the rebirth—of institutionalism has bred a wealth of studies of governance that have proven useful in explaining the stability, if not the outright inertia, of policies, public organiza-

\footnotetext{
*University of Canterbury

**Leiden University
}

Governance: An International Journal of Policy, Administration, and Institutions, Vol. 16, No. 2, April 2003 (pp. 235-270). (c) 2003 Blackwell Publishing, 350 Main St., Malden, MA 02148, USA, and 9600 Garsington Road, Oxford, OX4 2DQ, UK. ISSN 0952-1895 
tions, and governance structures. The literature contains many concepts and hypotheses that explain the durability of institutional arrangements: inheritance, immortality, stickiness, lock-in, deadlocks, path dependency, appropriateness, permanent failure, and so on. It is replete with empirical accounts of reform impasses (Reformstau has become a term in popular speech in Germany), reform paradoxes (Peters, Hesse, and Hood), and reform backlashes (Hirschman). Overcoming the many barriers to institutional change in policy-making is indeed a daunting task. The current policies and institutional arrangements are embedded in laws, protected by dominant coalitions, sustained by habituation and organizational inertia (Hogwood and Peters). Although it may be possible to "smuggle in" reform through a series of cumulative incremental policy adjustments (Lindblom; cf. Rose and Davies), this is a time-consuming, easily reversible, and potentially drifting process (Goodin).

Despite the obstacles, governments sometimes embark on the path of institutional reform - that is, deliberate and sustained attempts at nonincremental change in the substance and process of government. These reforms may take different shapes, including the adoption of innovative policies (Hermann; Polsby), the termination of strategic policy programs or projects (Brewer and DeLeon; Hogwood and Peters), paradigm shifts in entire sectors of public policy-making (Hall), major public-sector reorganization drives (Hesse and Benz; Olsen and Peters), and constitutional reengineering (Hesse and Johnson). Still, it appears that there are far more rhetorical and aborted than substantive and enduring reforms. Many reform drives never get off the ground or are rendered toothless in their implementation. Successful reforms-those that are adopted as designed by their sponsors-constitute a major political achievement. Thus, why they happen in some cases and not in others requires systematic study.

A body of literature has explained policy change largely in structural terms. However, while there may well be structural pressures for change, these only explain why change may occur, not the form change may take. Reforms, like decisions, do not just "happen" (cf. March); they are constructed, promoted, obstructed, negotiated, and modified in interactions between actors in institutionalized policy arenas (McFaul; see also Garrett and Lange). Structural accounts that factor out the role of policy-makers, policy leaders, or policy elites produce an eerie, dehumanized account of governance at the very junctures where "choice" is required, since "routine" is deemed inadequate. This does not square with the reality as experienced by participants and close observers of institutional reform episodes, and it ignores the role that statecraft plays in policy-making and institutional redesign (Dror). We need a richer, layered account of institutional reform, one that focuses on the interplay between macrolevel conditions, situational contingencies, and political interaction. In particular, we need to focus greater research attention on policy actors, policymakers, and policy leaders. 
Some policy analysts argue that governance unfolds through time as a pattern of "punctuated equilibriums"(Baumgartner and Jones): long eras of stability alternated by short-lived periods of uncertainty and conflict. They point to "critical junctures" during which existing policy settings, policy goals, and institutional arrangements for policy-making are under pressure and lose their self-evident legitimacy-in short, periods during which governance "deinstitutionalizes" (Suchman). They acknowledge that these are periods in which there is the potential for major changes, calling them "windows of opportunity for reform" (Keeler).

From there it is only a small step to suggest that for the reform potential of such crises to be fully exploited, policy-makers and policy leaders have to "seize the moment." This idea lies at the heart of John Kingdon's influential, yet primarily heuristic notion of "policy entrepreneurs." Policy entrepreneurs are individuals that are unusually adept at playing the political game of policy-making. They succeed in joining disparate streams of problem definitions, political priorities, and (coalitions of) actors in the policy arena to wield support for particular policy initiatives (see also Bryson and Crosby; Lynn).

The notion of policy entrepreneurship has its limits, however. Kingdon, for example, does not specify why certain individuals are able to play the role of policy entrepreneur in any given case. Nor does he operationalize the concept in a way that allows for systematic empirical research that enables us to observe its occurrence and impact apart from the known outcomes of the policy process (Mintrom and Vergari; Mucciaroni; see also Newmann). Also missing is an explanation of how leaders "seize the moment" and take advantage of the "window of opportunity" to advance their policy aims (Aberbach and Christensen).

To be successful, reformist leadership entails a number of functional requirements: it needs to articulate the need for reform, propose a set of radical reform objectives, see to it that these are politically sanctioned, and guard their integrity during implementation. In short, reformist leadership requires the embracing of novel policy ideas, the skills to "sell" them to diverse audiences, and the wielding of power to see them enacted (Bryson and Crosby; Marmor and Fellman; Moon). All this is to be done in an environment of inherent uncertainty about the outcomes of the ideas and, most likely, considerable resistance in societal, political, and bureaucratic arenas.

How, then, might we explain what leaders actually do when they go about seizing the moment to advance changes in policies and institutions? How do policy reformers use or create crisis to achieve their policy aims? How do policy leaders convince others of the need for reform, control the decision-making process, and see that reform is actually implemented? Drawing on the body of literature on policy change, we advance five hypotheses to explain the role of political and bureaucratic leadership in macroeconomic policy change. 


\section{CRISIS, LEADERSHIP, AND POLICY CHANGE}

Hypothesis 1: The more dramatically reformist leaders portray current events or issues and serious and acute crises, the higher the likelihood of reform success.

In Nelson Polsby's study of policy initiation in the United States and in John Keeler's comparative analysis of legislative activism, crises show up as crucial facilitators of change. This squares with findings of leadership studies. Borrowing from the literature on charisma and transformational leadership, this hypothesis argues that it is necessary for reformist leaders to create or seize upon an atmosphere of crisis (Bostdorff; Burns; House; Klein and House; van Dooren). We know from social psychology that if people can be persuaded that the system or crucial parts thereof are under serious and urgent threat and that conventional ways of counteracting the threat are not working, their willingness to accept unconventional measures increases (Edelman, 1971, 1977; Janis and Mann). As prospect theory predicts, in a crisis, the propensity for loss aversion is activated and is a much more powerful force in motivating risk-taking behavior than the desire to secure potential gains (Vertzberger). In other words, framing policy predicaments as crises provides potential momentum for policy reforms, since it helps to delegitimize and thus deinstitutionalize existing policies and structures. Reformist leaders may use crisis language to serve their strategic aims, provided they themselves are not at the same time being blamed for the occurrence of these crises. Hence, reformist leadership needs to dramatize the seriousness of the situation, yet, at the same time, "externalize" its causes.

Hypothesis 2: If reform leaders gather together allies to form a cohesive team in support of important changes, prospects for success are enhanced.

Fostering a sense of urgency for change is merely a first step in a leadership strategy of reform. An essential second component is communicating a personal commitment to the making of nonincremental changes to the status quo. This builds upon Jeremy Moon's concept of "political will." In his view, reformist leadership requires a clear sense of vision, and the ability to espouse a deliberately partisan view of the direction that policy should take. It entails "a determination to pursue policies beyond those which arise by force of circumstance" (Moon, 2). If leaders do not succeed in effectively articulating this willpower, critics will soon see through their lip service to "change." Moon describes Margaret Thatcher as a politician who became fully committed to change after an initial period of orientation and probing. Once her mind was set on pursuing neoliberal economic reforms, she made it clear that this was the direction she wanted to go in. At crucial moments, she was willing to take political risks to prevail against institutionalized resistance. Of course, the devil is in the dosage here: there is a fine line between effectively communicating resolve and descending into an autistic determination to seek reform at all costs. Driven by ideological fervor and/or by confidence 
gained from previous successes, reform zealots may come to self-anaesthetize their political antennas. Consequently, they overestimate the level of support they enjoy. The "later" Thatcher ran this risk, as many observers have commented (see, e.g., Young). A classic case of such selfdefeating overcommitment was U.S. President Woodrow Wilson in his dogged and doomed fight with the Senate over American participation in his brainchild, the League of Nations (George and George).

The effectiveness of reform commitment increases markedly when reform is not pushed by a sole operator, even if that operator happens to be the chief executive or most senior policy-maker. Even they benefit considerably from entering into partnerships. A number of writers have argued that reform drives can be led by political tandems or small-scale, hard-core coalitions of reformers. Shaun Goldfinch (1998) has noted the importance of a small, tightly knit, and long-lived policy community in driving the radical liberalization of the New Zealand economy. Similarly, Joe Wallis and Brian Dollery (116) have noted the importance of what they call "leadership networks" in policy change and policy leadership. As they (116) argue:

[T] he tasks of policy leadership required to institutionalize a new policy paradigm must be collectively supplied. A network of policy leaders must be formed which seeks to place its own members in positions of leverage over the agenda-setting, formulation, decision-making, implementation, and evaluation stages of the reform process. This concept of leadership ties in with much of the modern writing on the subject which tends to emphasize the collective dimensions of this phenomenon.

Other examples abound, including Nixon and Kissinger in U.S. foreign policy and Kohl and Genscher in German unification. Acting in tandem with other key players in the policy arena-be they policy-makers, senior bureaucrats, or leaders of social-interest groups-has many benefits. Internally, it provides individual reformers with an opportunity for both social support (drive and zest) and tactical reality-testing. In the face of less-than-perfect policy outcomes during and after the reform process, these contacts can "counter the dissonance [experienced] as a result of ... disappointments" (Wallis and Dollery, 154). Externally, members of a reformist "clique" may cover complementary organizational and political bases. For example, reformists may strive to appoint similarly minded colleagues and friends to positions of influence across the policy spectrum to further facilitate the reform drive.

Hypothesis 3: If reformers develop and employ strategies targeted at persuading their political environment that the proposed changes are both desirable and inevitable, as well as being practically feasible, they are more likely to be successful.

Some policy-makers and commentators have made a virtue of a "crash through" approach to policy reform, arguing that rather than convincing the population of the benefits of the reforms before change, these bene- 
fits will become apparent after change is achieved (Douglas; Williamson 1994a, 1994b). As former New Zealand Finance Minister and economic liberalization champion Roger Douglas (220-221) says: "Do not try and advance a step at a time. Define your objectives clearly and move towards them in quantum leaps. Otherwise the interest groups will have time to moblise and drag you down." In New Zealand's economic reforms, Wallis has argued, policy change was an example of "conspiracy" in which change was introduced quickly, in large packages, sometimes in secret, and in the face of explicit election promises to the contrary.

However, as Neustadt-amongst others—has argued, successful political leadership is often about persuasion. Simple commands and intimidation may not work in pluralistic polities. Indeed, crash-through approaches run the risk of alienating the very electorate and population that is the supposed beneficiary of the reform processes. This can lead to anti-reform backlashes, "change fatigue" where electorates and some politicians become suspicious of policy change whatever the direction, and, in some examples, electoral instability. In severe cases, the legitimacy of the political system may be undermined (Goldfinch 1998). Instead of trying to force actors in their political environment to conform to their preferred policies, political leaders may need to present persuasive arguments to get their associates to identify with their aims and internalize their own policy preferences. Reformist political leaders, in particular, have a lot of persuading to do, since what they want differs markedly from what exists. They have to use their analytical and rhetorical skills not only on the soapbox-for example, in macropolitical arenas aimed at large audiences (mass media, public opinion, specific target groups, and increasingly also global markets and international organizations)—but also in the micropolitical confines of the Cabinet, the party, and legislative committees. They have to persuade these multiple audiences of an intricate policy argument: what we want is good, it is realistic, and, at the very least, it is inevitable given the situation that we all are in; while what our opponents want is bad, unrealistic, and by no means necessary. This not only requires effective command and selection of facts and the rhetorical skills to present them, but also touches upon the socioemotional bond between leaders and their social environment.

Leaders need to do more than expose a crisis; they also need to reassure followers that they have the right, if not the only, way out. Leaders need to foster confidence in their judgment and leave no doubt as to their superior qualifications to lead the community through the reform process. As Wallis and Dollery (154) theorize, reform leaders need to develop "hope" amongst those involved in the policy reform process, with the "interaction between agents who share the same hope... likely to build up the beliefs, emotional energy, and action tendencies that underlie, sustain, and are expressed by this emotion. This should also sustain their commitment to advance the [reform] quest." Reformist leadership needs to be constructive and destructive at the same time: build up its own case, 
burn down the bridges to the past, and disqualify competitors. To some extent, therefore, radical reforms need to be "oversold" to persuade constituencies that a sharp break with the past is in their interests; Helmut Kohl's promise of the blühende Landschaften (green pastures) that would result from German unification is a case in point.

Hypothesis 4: Successful reformist leaders manage to secure early support of implementing actors for their crisis-response strategy.

Many studies of policy change and institutional reform focus on the development and political adoption of reform proposals. This is unlikely to satisfy students of bureaucratic politics and policy implementation, who have demonstrated time and again that, especially when highly contentious policies are at stake (as major reforms usually are), the infighting between advocates and critics continues unabated after the formal decisions have been reached. Implementation boils down to the continuation of politics by other means, partly by other players and partly in different arenas. This may well result in the delay, distortion, or even complete discarding of reforms that political decision-makers had assumed would take effect (see Bardach; Boin and Otten). A rather dramatic example is the abandonment of aspects of health and other social policy reforms in New Zealand in the early 1990s. These were introduced with limited consultation with professional or societal interests, and in some cases with active avoidance of such consultation (Barnett and Jacobs; Boston).

In contrast, effective reformist leadership requires anticipation of implementation obstacles. It needs to display an awareness of implementation structures, identify the key players (these may well reside at different levels of government or in semipublic and private organizations), and build sufficient support among them. Given the organizational heterogeneity, the ties to powerful clienteles, and the professional autonomy that many implementing bodies enjoy, the failure to consult them and seek their support at the policy-design stage cannot be compensated for by later insisting upon a stringent top-down oversight of the implementation process.

Hypothesis 5: The tighter the leadership's control over the crisis-management process, the higher the likelihood of reform success.

The literature on collective and collegial decision-making in government suggests that an important dimension of the political efficacy of presidents, prime ministers, and other leaders lies in their institutional ability to influence the organization of decision-making - that is, to exercise procedural leadership (Andeweg; Baylis; Dunleavy and Rhodes; Elgie; Hargrove; James; Rhodes). The bigger their constitutional scope or political mandate in laying down the rules of the game, the more they are able to adopt the policies they prefer. The rules of the game may, amongst others, pertain to the selection of people in key positions, the participa- 
tion in core decision units, and the modes by which collective choices are made (Hoyt and Garrison; Maoz; Stern and Verbeek; 't Hart). It is common to distinguish between "weak" and "strong" chief executives based on these positional criteria (Weller). Margaret Thatcher has been widely noted as a prime minister who used her power of appointment to Cabinet and senior civil-service positions to secure a power base needed to forge the policy reforms she intended to make (James; Moon; Young). In New Zealand, members of the reform-policy community appointed like-thinking colleagues and friends to positions of power on important task forces and to the boards of state-owned enterprises and the Reserve Bank (Goldfinch 2000; Wallis and Dollery).

The formal, structural dimension is only one dimension of control over the decision-making process. There is also the more substantive side: policy-makers who take the initiative in framing the problem and proposing solutions improve the chances of these solutions being accepted. To this end, decision-makers may not simply use the force of argument; they may also resort to more manipulative tactics, such as using their monopoly on certain types of policy-relevant information to present their colleagues in the relevant decision units with a highly stylized picture of the issues involved (Maoz). This type of manufacturing consent is one area in which reformist leaders convince themselves that they face the choice of being effective or being ethical.

In short, the approach to understanding reformist political leadership developed here evolves around four critical C's: Crisis, Communication, Commitment, and Coalitions. Reformist leaders wait for contingencies in their environment that they can portray as serious crises requiring urgent and hitherto unavailable policies. They communicate not only this image of crisis but also their commitment and ability to resolve the predicament. In order to do so successfully, they engage in hard-core reform coalitions with trusted associates and use their procedural influence to form pragmatic coalitions with parties whose support is vital in seeing the hard-core's reform proposals through politically and in getting them implemented.

Let us now turn to the Australian case studies to explore the viability of the propositional framework developed above.

\section{CRISIS MANAGEMENT AND INSTITUTIONAL REFORM IN AUSTRALIA}

By the time of the election of the Labor Government in March 1983, the Australian economy was under some stress. After the oil shock of 1973-1974, Australia entered a period of relative economic decline. For example, from 1971 to 1981, gross domestic production (GDP) per capita measured by purchasing power parities grew at 3.2 percent, compared to the OECD average of 3.4 percent; terms of trade were on a downward trend from the highs of the early 1970s, and manufacturing had declined as a percentage of exports. Despite a mining boom in the early 1980s, by 
the time of the 1983 election, Australia was in a severe recession. The economy shrank by 1.7 percent in 1982-1983; unemployment stood at 10 percent and annual inflation at 11 percent, and the current account deficit was running at over 3.8 percent of GDP. Despite some early success by the previous coalition government of Malcom Fraser in constraining the fiscal deficit, by 1982-1983 the deficit had expanded to 2.6 percent of GDP.

If looked at with the benefit of hindsight, actual decline was somewhat marginal, and it is possible that Fraser's fiscal stimulus would have taken the economy out of recession. However, for a nation that perceived itself (only sometimes ironically) as the "lucky country" and that was accustomed to being at the forefront of world economic performance, this relative decline was often perceived as a crisis. There had been growing pressure from various quarters for further liberalization of the economy, including trade liberalization, and if Fraser's economic policies did not lead to as poor economic performance, as commonly believed, they did not accord with the growing policy-elite consensus for further economic liberalization. To some extent, there was a crisis in the minds of some policy-makers almost by definition, because policies were not entirely as economic orthodoxy would have them. Thus, whatever the reality of the economic crisis, there was at least a strong perception that policies were not working, and that things had to change.

This feeling of crisis was augmented on the election night in Canberra, on 5 March 1983. The victorious Australian Labor Party (ALP) elite was gathered at the Lakeside Hotel on the border of Lake Burley Griffin in the heart of Australia's capital. Amidst the general mood of elation, a phone call came in for Prime Minister-Elect Bob Hawke and the designated treasurer, Paul Keating. The man on the phone was the Secretary of the Treasury, John Stone. Stone requested a meeting the next day concerning the budget estimates for the next fiscal year. When he arrived at the hotel along with another Treasury official, he brought news: whereas the previous government had published estimates that put the projected deficit at $\mathrm{A} \$ 6$ billion, Stone now reported that the actual deficit would most likely be around $\$ 9.6$ billion. The fiscal blowout was not a total surprise, and it is probable that something had been leaked from the public service to the Labor opposition. Hawke had said the day before the election that if the fiscal situation was worse than expected, some election promises would have to be revised. He had also been tipped off about the fiscal "blowout" late in the election campaign. In any event, the news was not all bad. As one Keating staffer noted:

Stone handed to me, the first person to receive this, the view and prospect that the deficit was going to be 9.6B. In effect what had happened was that the Fraser Government... had thrown money at the budget. It turned out there was already enough stimulus in the economy. The government was in the very fortunate position to be able to stimulate the economy fiscally while appearing to be conservative by cutting back. (Interview, Canberra 1997) 
Hawke (143) later reminisced that "I knew we had struck political gold."

He and Keating immediately went on the offensive, turning the crisis into an opportunity. After some debate, they decided to devalue the Australian dollar by 10 percent. Waving the Treasury document in front of all the TV cameras at the dramatic announcement two days later, and consistently coming back to it in the months and years to come, they succeeded in discrediting the Liberals' claim to be Labor's natural superior in managing the economy and maintaining fiscal responsibility. The Stone paper thus became "one of the most lethal documents in Australia's political history" (Kelly, 57). Hawke and Keating used the ominous Treasury estimates to foster a sense of crisis among their Cabinet colleagues and the ALP in general, providing them with the political support to maintain fiscal rectitude, to abandon some election promises, and to "reconfigure" others (Goldfinch 2000).

Although they probably did not realize it then and there, Hawke and Keating's response to the budget crisis was a first step in a period of restructuring and reform unprecedented in Australia's political history. Labor would be in power for thirteen years, winning five consecutive elections. Keating would eventually replace Hawke as Labor leader and prime minister, following an intensely personal power struggle that paralyzed the government for most of 1991. When Labor was finally defeated at the 1996 elections, it left a country whose economy had been transformed into one of the most open in the OECD. Trade protection was amongst the lowest in the developed world; financial, capital, and other markets had been extensively deregulated; privatization receipts were second in the OECD as a percentage of GDP; and there was a significant degree of liberalization of the labor market through the Accord process.

This remarkable period of change gives us a useful opportunity to test our hypotheses. Investigating four "framing-breaking episodes" early in the life of the Labor Government that arguably set the pattern for the further economic liberalization that was to follow, we will evaluate how well our hypotheses illuminate policy change and the role of crisis and leadership in this change.

\section{Catalysts of Institutional Reform: Four Critical Episodes}

To understand the genesis of economic reform in Australia, we examine four crucial, "frame-breaking" episodes. In three of these cases, the reform proponents obtained their preferred reform outcomes; in one, they did not (although an incremental reform package was eventually accepted). One of the major tasks for the analysis is to explain why three successes and one failure occurred.

All of the ministers in Hawke's Cabinet belonged to the ALP. Key portfolios in the economics domain were held by: Paul Keating, Treasurer; John Button, Minister for Industry; John Dawkins, Minister of Finance 
(Minister of Trade from 1984 on); Ralph Willis, Minister for Employment and Industrial Relations; and Peter Walsh, Minister of Energy (Minister of Finance from 1984 on). Most of the important decisions on the budget and other economic matters were negotiated and de facto taken in the Expenditure Review Committee, consisting initially of Hawke, Keating, Willis, Dawkins, and Walsh and later expanded. Major policy decisions were mostly, but not always, taken to formal Cabinet meetings. In one of the four cases (tax reform), the Prime Minister ruled that the case for the (revised) reform proposal should be argued before the full ministry (Cabinet members and junior ministers). Within the government, three party factions were operating. These reflected long-standing and historically bitter divisions within the ALP, based partly on ideological and partly on geographic grounds. Under Hawke, the faction system worked well as a means of mediating potential conflict, and internal party infighting was not a major factor affecting the cases studied here. After Cabinet approval, the final major political hurdle was usually the Labor caucus, the meeting of all the Labor MPs. In some cases (notably banking deregulation), the case was taken to the annual ALP conference.

In the executive arena, key roles were played by the Treasury (headed first by John Stone, who was succeeded in August 1984 by Bernie Fraser), the Federal Reserve Bank (headed by Governor Bob Johnston), and the Department of Prime Minister and Cabinet, with the Ministry of Finance particularly important in the budget process. ${ }^{1}$ In one case (the decision to float the currency), considerable tension existed between the Treasury and the Reserve Bank, and its upshot was a significant gain in political access and policy influence of the Bank's key officials. At the same time-particularly after Stone's exit as Treasury Secretary-an unprecedented bond developed between Treasurer Keating and his senior Treasury advisers, including Stone's successor, Fraser. This continued when Fraser became Governor of the Reserve Bank, to the extent that Keating talked to Fraser on unrecorded telephone calls. This group of officials was a key source of the steady stream of economic reform proposals put forward during the Labor Government. Apart from the government departments, Hawke and Keating both had small but highly qualified and, at times, very influential personal staffs, the members of which combined economic expertise with political astuteness and considerable experience in the bureaucracy.

Economic policy-making in Australia has no corporatist tradition (Bell). Labor relations have been relatively adversarial. Business is comparatively weakly organized in the political arena. In the 1970s and early 1980s, the relationships between government and the trade unions (including the increasingly important spearhead of the union movement, the Australian Council of Trade Unions-ACTU) had been marred by a lack of trust and cooperation, a tug of war sometimes flaring up into open confrontation.

In sum, the institutional structure of economic policy-making made it possible, in principle, to have a fairly closed approach dominated by a 
group of key ministers and departments. This could only work in practice if these key players effectively anticipated and attended to the complex sensitivities of ALP intraparty politics and worked within the constraints provided by Australia's sometimes complex federal system and the powerful house of review in the Senate. It was also believed that trade-union collaboration would be key to successful economic crisis management. The first major reform task, therefore, was to create an institutional mechanism for fostering this collaboration.

\section{The Economic Summit and the Accord (April-July 1983)}

Upon assuming office, the priorities for Hawke and other members of his government were to break the existing policy deadlock in the field of wage-setting and industrial relations and, more broadly, to create a broad national consensus on the fundamentals of an economic strategy designed to lead the country out of the then-current malaise of recession, low profits, and high unemployment. The Accord was part of the solution. $^{2}$ As well as showing that the Labor opposition had the support of the union movement going into the 1983 election, it also gave a hopefully credible response to the economic problems of the time and to the seemingly ineffective "fight inflation first" policy of the Fraser government. As Willis, one-time shadow Treasurer, noted, the Accord provided

a credible anti-inflation policy. What we were looking at was the then-Fraser Government's policy of letting the economy take off then having inflation boost up high wage claims and then hitting all the panic buttons at once ... a totally disastrous policy. (Goldfinch 2000, 155)

Consensus had been lacking throughout the Fraser period. Industrial relations in general were bad, and the Fraser government had antagonized the unions. With the support of some other officials, Hawke and his staff organized a multiday Economic Summit Conference in April 1983 at which the broadest possible range of economic and social-interest-group representatives met and presented their views on the crisis and what ought to be done. Despite a good deal of skepticism on the part of Keating, other Labor leaders, and political commentators (Mills, 36-37), the summit approach proved a success, at least in terms of signing the participants up to support the new policy directions of the new government-especially the Accord. Some business leaders were skeptical, with one former president of the Business Council of Australia seeing the summit as

a disaster. It was a popularly held belief that the communique from the Summit was probably written before it even took place. It is generally accepted that business was rolled. (Goldfinch 2000, 44)

However, others were more supportive, with some actively involved in the process. To some extent, Hawke's consensus message was an idea whose 
time had come. Under his leadership, institutional enemies were seated side by side, interacted informally, and, according to Hawke (179), found out to their astonishment that the "other side" was not so bad after all.

The summit facilitated the beginning of a more constructive public debate about wage restraint, deficit reduction, and the need for business and labor to cooperate in combating the economic crisis. Furthermore, the summit was instrumental in cementing the so-called Accord between Labor and the ACTU, which had been promoted during the election campaign but took on greater substance in July 1983. Under this agreement, the unions agreed to accept wage restraint in exchange for increases in the social wage. Negotiations regarding the Accord had been carried out between the Labor opposition and the ACTU over a number of years before the 1983 election, being finalized only after the snap election was called (Singleton 1990). According to Willis,

I was the architect of it. It was put together in opposition by myself, Bill Kelty and Jan Marsh [both of the ACTU]. It wasn't just we three, [but] we were the three that did most of the work, but towards the end when it was being put together a lot of other people had to become involved. The Labor party, the shadow ministers because we were getting in to the areas of social security, health policy, education, industry policy, etc. As it broadened in scope various people with key interests had to be brought in. (Goldfinch 2000, 155)

While Hawke was probably not the initiator of the Accord, his became its public face and his support was a vital factor in its success. As a former ACTU president, he was known and trusted by the ACTU leadership. Keating, however, was initially skeptical about the extent of the ACTU's commitment and the Accord process in general. This was because, according to Willis,

he had never been involved and his department was very skeptical. He tolerated or was skeptical about the Accord until we hit the fence 1985-6 with a need for a major devaluation of the Australian dollar, the need therefore for a real wage reduction [otherwise] we would get a major devaluation inflation cycle. Through the Accord [we managed] a reduction of real wages. The Treasurer was intimately involved in that and that got him onside with the Accord and he became a key player in the Accord from that time on. (Goldfinch 2000, 156)

When Keating eventually became convinced that the unions were serious and that the Accord could deliver real benefits, he developed into the Accord's main patron and guardian within the government. Together with Willis, yet increasingly based on a close personal relationship between Keating and ACTU General Secretary Bill Kelty-to the extent that Willis became somewhat sidelined-Keating and his staff negotiated six more accords. These moved from the centralized wage indexation introduced in the first Accord to, over time, encouraging a decentralization of wage bargaining, increases in worker productivity, and a move towards enterprise bargaining. 
The Float of the Dollar and the Lifting of Exchange Controls (December 1983)

The decision to float the Australian dollar was made at a hastily summoned Cabinet meeting on the afternoon of Friday 9 December 1983. It was triggered by the expectation of a speculative inflow of foreign currency, estimated at $\$ 3-4$ billion for that day. The reason behind the crisis was that speculators were expecting a revaluation of the dollar. In the first days of government, a spectacular 10-percent devaluation had been put into effect to stop the massive capital outflow that had been triggered by strong anti-Labor campaign rhetoric by then-Prime Minister Fraser. Market operators now figured that the dollar was undervalued and would appreciate, and they directed their money to Australia, causing major trouble for the Reserve Bank in managing the money supply and the exchange rate. This type of crisis was becoming endemic, and there was a strong feeling that a drastic change was necessary to stop these speculatory flows.

Pictured in this way, the decision to abolish the forty-eight-year-old system of managed exchanged rates has the semblance of a pure crisis reflex. However, it had been in the making well before the Hawke government came to power. The Reserve Bank, for example, had been in favor of a float since the late 1970s for various reasons, and this belief was only reinforced by the events after 1983. As a former Governor of the Bank noted,

We had come to the view ... in the 70 s and into the $80 \mathrm{~s} .$. that the regulated system couldn't be retained for two reasons. These were practical reasons. The exchange controls affected the honest and honourable and those people who were not in those categories went their own way.

Secondly, [with] the change of government in 1983, we had put the existing exchange mechanism to the ultimate test. Having had a floating peg arrangement, we had to have a straight-out devaluation in the aftermath of the election; we couldn't very well go back to the old system. (Goldfinch 2000, 161-162)

Along with the Bank, Hawke's personal advisers, as well as key officials within the Department of Prime Minister and Cabinet, were also advocating the idea of currency reform. Hawke accepted their analysis and became a supporter of a float. Independently from Hawke, Keating did the same, although he had to tread very carefully. He was new to the field of finance and had to navigate on unfamiliar terrain. Moreover, he received conflicting advice: very strong opposition to a float from the Treasury, in particular its powerful secretary, John Stone; very strong support from the Reserve Bank. In addition, Hawke and Keating were both constrained by the political heritage of the Labor shadow government under Hayden, which had come out very strongly against a float in 1982, when the Fraser-nominated Campbell committee had recommended it. At the time, Fraser had vetoed a float, against the view of his Treasurer, John Howard. Despite these political sensitivities, Keating had held discussions with the Reserve Bank as early as April 1983 on how to combat the speculative inflows and outflows of 
capital. He and Hawke soon agreed on the need for reform, and set about making it happen.

In May 1983, Keating and the Treasury arranged for a new study group headed by Vic Martin, a prominent business leader, which was sure to recycle the pro-deregulation agenda advocated by the Campbell committee. It also included Keith Hancock, involved because of his good standing with the Labor party. The Martin review group largely repackaged the recommendations of the Campbell report to "make them palatable to the Labor Party" (Goldfinch 2000, 160), as one former Treasury Secretary termed it, using less analysis and different language than the Campbell report. The political significance of the Martin committee was that it was appointed by a Labor and not a coalition (Liberal/National party) government. The message Keating and Hawke sought to convey was that deregulation was not a conservative policythat, in fact, the ALP should change its party platform and accept that opening up financial markets was inevitable and, moreover, beneficial to ordinary Australians, not just to big business.

Meanwhile, events on the currency market speeded up the process. Small appreciations of the dollar were taking place, hurting the Australian export position and allowing speculators to make a profit in U.S. dollars against the Australian currency, de facto paid for by the Reserve Bank. There was an unsuccessful attempt to obtain an interim report supporting the float from the Martin committee. The Reserve Bank maintained the pressure to move to a float.

Several meetings took place in early October between Keating and Treasury officials, as well as broader meetings including the Reserve Bank leaders and Hawke's staff. Members of the Department of Prime Minister and Cabinet also supported the float. Slowly, the balance of power tilted against Treasury (more so because it became clear that there was a difference of opinion within the senior ranks of Treasury). At the end of October, the most severe currency inflow crisis thus far took place. Still, Stone could not be moved. By way of compromise, the decision was made to float the forward rate (the exchange rate today for settlement later) but to keep the spot rate (the exchange rate at the present time) under government control. Keating abided by the compromise, but told Stone that next time a crisis came, the float would have to go through, and that he expected Treasury to fall into line.

The bureau-political fight then switched towards the issue of exchange controls (the government's ability to monitor and modify large purchases and sales of Australian dollars). Even if the currency was fully floated, the exchange controls would soften the impact of market forces and would still allow government to keep a foot in the door, which is what Stone wanted. The Reserve Bank and Keating's and Hawke's advisers all wanted a maximum market situation. The December crisis provided the last push: the spot rate was floated and, soon afterwards, exchange controls were lifted. Australia was now firmly locked into the international 
financial system (Carew, 95-105; Edwards 1996, 205-235; Goldfinch 2000; Hawke, 234-250; Keating, 543-548; Kelly, 76-94).

The floating of the Australian currency and the lifting of exchange controls were probably the most far-reaching of the four reform episodes discussed here. The float has sometimes been branded, with a degree of hyperbole, as the single most important decision in Australia's postwar political history. Moreover, it was seen as having spillover effects and was portrayed as making further deregulation almost inevitable.

\section{Banking Deregulation (July 1984)}

On the heels of the successful assault on the fixed-rate exchange system came the push to reduce the regulatory constraints on banks. Under Fraser, the Campbell committee had recommended deregulation of the banking sector, but the political will had been lacking. Now there was momentum. Since the Australian currency had been opened up to world markets and controls on foreign-currency transactions had been lifted, doing likewise with the Australian banking system could be presented as a natural-almost a necessary-follow-up step. Under the existing system, a very limited number of licensed, domestic banks were allowed to dominate the market. Following the Campbell recommendation-confirmed in February 1984 by the report of the Martin review group-and after lobbying from foreign banks and governments, Keating decided to move. He advocated liberalization of financial services, specifically to allow foreign banks to compete on the Australian market and to allow competition between banks and nonbanks for the provision of various financial services. With this move backed by Hawke and presented to the Cabinet as a fait accompli, Keating set about the task of persuading first the Labor caucus and then the full Party Conference. At the time, Labor opinion was still weary of market solutions, even when it came to not particularly cherished institutions such as banks. Keating, however, was very effective in arguing that under the existing oligopoly, the four big banks had not done very well for ordinary consumers and households. On the contrary, their rates were artificially high and their service poor. Increased competition would change that, he argued. His "what have those banks ever done for us" line won the day, and a solid majority at the ALP conference supported this next step in the transformation of the Australian economy. After an application procedure, Keating announced triumphantly in February 1985 that no less than sixteen foreign banks would be licensed to operate in Australia, sending shockwaves through the banking community.

\section{Tax Reform (August-October 1985)}

It began as an off-the-cuff campaign pledge by Hawke to hold a national summit meeting on tax reform, and it quickly developed into an all-out effort by Keating to achieve what was labeled by Deputy Treasury 
Secretary David Morgan - with hyperbole uncharacteristic for a Treasury official-as "by far the biggest single reform in the history of the Federation" (ABC Television). It resulted in the defeat of the package, but the subsequent acceptance of a dressed-down tax reform proposal.

Hawke's late-1984 pledge was an effort to repeat the 1983 success of reform by consensus. The circumstances were quite different, however. In early 1985, there was no widespread belief in an economic crisis. The economy was booming, and people were ready to reap the benefits, not to be bothered with new tax burdens. Hawke had pledged that tax reforms would only be made on the basis of national consensus, yet tax by its very nature tends to be a divisive issue.

The tax summit grew out of electioneering before the 1984 election. The opposition was claiming that the government would introduce a capital gains tax, as well as death and gift duties. In the offices of the Prime Minister and the Treasurer, a set of principles regarding tax were developed that evolved into the so-called Trilogy Commitment. This was a promise to not increase spending as a proportion of GDP, to not increase the overall tax burden, and to not increase the fiscal deficit. According to a member of Keating's staff, "the objectives were what Keating called 'to end the tax blackmail' [and to] try to get through the election campaign without ruling out tax changes that needed to be considered" (Goldfinch 2000, 169). However, Hawke unilaterally announced a tax summit during a radio program, without consulting his staff and Cabinet colleagues. Keating was unhappy with the summit idea from the start: "I could think of nothing worse than making tax policy in public. Nothing worse. It was the antithesis of political efficiency" (ABC). Yet he was stuck with it.

Treasury analysis had convinced Keating of the need to change the tax system. It contained too many loopholes, and, Treasury argued, benefited the rich. Treasury lobbied very heavily for the closing of loopholes and for a broadening of the tax base from a system leaning predominantly on income tax to a mixed system, with a prominent role for a new consumption tax to be levied on all goods and services. Direct taxes, it was argued, would be more effective in gaining revenue and more efficient to administer. The potential regressive social effects of such a universal GST would have to be compensated for by flanking measures for low-income earners. Through the early months of 1985, an intensive effort went on to prepare a government tax package and to gain the necessary bureaucratic, political, and community support. Treasury formed a task force, found an unused basement in its building, and set up camp there to do the analysis. Three options emerged: option A (a broadening of the tax base through, among others, a capital gains tax, reduction of exemptions, and measures to ensure compliance, and a simultaneous reduction of the top income-tax rate); option B (all this and a further reduction in income-tax rates, to be paid for by a 5-percent GST); and option $\mathrm{C}$ (even greater reductions in income tax and a 12.5-percent GST). 
Option $\mathrm{C}$ was the preferred package from the Treasury point of view. It was, however, political dynamite. Hawke was lobbied incessantly by his political advisers to stop the process. Keating and Treasury were trying to pull him in the other direction. This game for Hawke's favor was played out during a series of meetings in which, time and again, Keating and his people came away thinking they had managed to get the Prime Minister on board, only to find out afterwards that there had been some backsliding. Hawke was ready to test the proposal, but not to support it unequivocally. For the reform zealots, it was a painstaking process. Looming in the background was the fierce opposition to a consumption tax that could be expected from the community, not in the least from ALP voters. It was a hotly contested, emotional issue ("tax on food and shelter"').

Keating had to persuade the Cabinet, the ALP caucus, Parliament, and the Australian people to accept something they did not want-a formidable challenge. Yet he was unstoppable. As Paul Kelly (170) put it, his determination anaesthetized his political antenna. His tactic was to burn his bridges and to destroy Labor's options: "He depicted the existing system as unsustainable; therefore it had to be changed radically. Keating's aim was to generate such a momentum for reform that the politics would be transformed-that retreat would be seen as political cowardice and that biting the tax bullet would become the lesser electoral risk" (Kelly, 160). After two and a half days of acrimonious debate, Keating succeeded in carrying the Cabinet. It was not easy, but he rose to the challenge. One witness reminisced: "He used rationality, he used his intellect, he used his charm, he used his humour, he used his anger, he used his theatrics, he used his spleen, he used his withering language ... It was the most remarkable performance I have ever seen during my years in the Cabinet room" (ABC). Throughout the meeting, Hawke kept his cards close to his chest. He managed the process and supported Keating's effort, but he did not jointly advocate option $C$ in the face of resistance from other ministers.

After Keating won the Cabinet over, a month-long intensive effort in the form of an election-style campaign was undertaken to persuade public opinion of the merits of the reform. However, polling figures taken at the time showed that an overwhelming majority of people were against the consumption tax. Massive protest demonstrations by interest groups such as the farmers underlined the difficulty of combining tax reform with consensus politics.

The Taxation Summit, held at the end of June 1985, drove the message home. One speaker after another argued against option C. Even business came out against it. Keating was beaten, but refused to surrender. In the end, Hawke went behind his back and did a deal with the ACTU, which both realized held de facto veto power over any tax proposal. Option $\mathrm{C}$ was dead. Keating made a gracious retreat (at least publicly), and found new strength to devise a revised package not containing any consump- 
tion tax, which he forced through Cabinet in another marathon session in September (Carew, 112-126; Edwards 1996, 253-285; Hawke, 294-314; Richardson, 176-186; Walsh, 141-148).

Table 1 summarizes and compares the main features of the decision-making process with regard to these four reforms. It should be noted that although they are treated more or less as separate policy episodes occurring in a common institutional and political context and acted out by essentially the same set of key actors, in reality the cases are-for that very reason-linked. The relative ease with which banking deregulation progressed through the political system cannot be understood without viewing it as part of a reform wave, the beginning of which had been marked by the currency float. Reform proponentsKeating being the most prominent one-gained momentum following every reform struggle won, making it easier (even if only in their own minds) to take on the next reform challenge. In this sense, then, "learning" occurred throughout the period between 1983 and 1985 examined here, which to some extent "contaminates" the case findings. On the other hand, the fact that Keating was defeated at the Tax Summit indicates that a reform struggle can never be won on momentum gained by past successes alone. To a considerable extent, actors will weigh the arguments and the politics of each major reform initiative on their own merits.

\section{REFORMIST LEADERSHIP IN AUSTRALIA: A COMPARATIVE ANALYSIS}

\section{Institutional Reform in Australia: Necessity and Choice}

It is tempting-certainly so in retrospect-to play down the role of politics and politicians in the institutional reform of the Australian economy. This is done by economic analysts pointing to global trends in financial markets, the structural weaknesses of the Australian economy, and the worldwide impact of new economic ideas (Emy and Hughes, 10-11, 23-26; Harper and Leslie, 89-95; Emy, 15-18). While there were systemic pressures at work, these deterministic accounts significantly underestimate the degree of opposition to reform that existed within Australia. Nor do structural imperatives (whether called, amongst other things, globalization, internationalization, or the logics of capitalism) make certain policy responses inevitable, even if these pressures are as great as some of their more enthusiastic proponents claim. These pressures may make change more likely: they do not determine the type, direction, or intensity of change. There is certainly no one policy response to economic imperatives, whatever they may be, and various studies of economic and social policy across the world make claims of "there is no alternative" difficult to maintain for all but those largely impervious to actual evidence. As Ross Garnaut (64), a professor of economics and a former advisor in Hawke's office, noted: 
TABLE 1

Reformist Leadership in Australia: Four Cases

\begin{tabular}{|c|c|c|c|c|}
\hline & $\begin{array}{c}\text { Economic } \\
\text { Summit } \\
\text { (March 1983) }\end{array}$ & $\begin{array}{c}\text { Dollar Float } \\
\text { (December } \\
\text { 1983) }\end{array}$ & $\begin{array}{c}\text { Banking } \\
\text { Deregulation } \\
\text { (Winter 1984) }\end{array}$ & $\begin{array}{l}\text { Tax Summit } \\
\text { (July 1985) }\end{array}$ \\
\hline Key issue & $\begin{array}{l}\text { How to combat } \\
\text { stagflation } \\
\text { during } \\
\text { economic } \\
\text { crisis? How to } \\
\text { prevent new } \\
\text { Labor } \\
\text { government } \\
\text { from being } \\
\text { paralyzed by } \\
\text { wage claims } \\
\text { and market } \\
\text { distrust? }\end{array}$ & $\begin{array}{l}\text { How to stop } \\
\text { incessant and } \\
\text { destabilizing } \\
\text { speculation } \\
\text { against } \\
\text { Australian } \\
\text { dollar in } \\
\text { volatile } \\
\text { economy? }\end{array}$ & $\begin{array}{l}\text { How to follow } \\
\text { through on } \\
\text { the path of } \\
\text { financial } \\
\text { deregulation } \\
\text { inaugurated } \\
\text { by dollar } \\
\text { float? }\end{array}$ & $\begin{array}{l}\text { How to } \\
\text { design a } \\
\text { more effective } \\
\text { and equitable } \\
\text { tax system? }\end{array}$ \\
\hline $\begin{array}{l}\text { Reform } \\
\text { proponents }\end{array}$ & $\begin{array}{l}\text { Prime } \\
\text { Minister }\end{array}$ & $\begin{array}{l}\text { Prime Minister } \\
\text { and staff; } \\
\text { Treasurer and } \\
\text { staff; Reserve } \\
\text { Bank; Department } \\
\text { of Prime Minister } \\
\text { and Cabinet }\end{array}$ & $\begin{array}{l}\text { Treasurer } \\
\text { (backed by } \\
\text { Prime } \\
\text { Minister) }\end{array}$ & $\begin{array}{l}\text { Treasurer } \\
\text { and staff } \\
\text { Treasury } \\
\text { Department }\end{array}$ \\
\hline $\begin{array}{l}\text { Reform } \\
\text { opponents } \\
\text { (internal) }\end{array}$ & $\begin{array}{l}\text { Considerable } \\
\text { skepticism in } \\
\text { Cabinet, but } \\
\text { no active } \\
\text { resistance }\end{array}$ & $\begin{array}{l}\text { (Secretary of) } \\
\text { Treasury } \\
\text { Department }\end{array}$ & None & $\begin{array}{l}\text { Major } \\
\text { opposition } \\
\text { within ERC } \\
\text { and Cabinet; } \\
\text { Finance } \\
\text { Department }\end{array}$ \\
\hline $\begin{array}{l}\text { Reform } \\
\text { opponents } \\
\text { (external) }\end{array}$ & $\begin{array}{l}\text { Negligible } \\
\text { ("wait and see" } \\
\text { skepticism) }\end{array}$ & $\begin{array}{l}\text { ALP } \\
\text { traditionalists }\end{array}$ & $\begin{array}{l}\text { ALP } \\
\text { traditionalists } \\
\text { in caucus and } \\
\text { party at large }\end{array}$ & $\begin{array}{l}\text { ACTU; } \\
\text { business; } \\
\text { public } \\
\text { opinion }\end{array}$ \\
\hline $\begin{array}{l}\text { Main locus } \\
\text { of reform } \\
\text { struggle }\end{array}$ & $\begin{array}{l}\text { National } \\
\text { Economic } \\
\text { Summit }\end{array}$ & $\begin{array}{l}\text { Ad hoc and } \\
\text { crisis meetings } \\
\text { of key } \\
\text { ministers, } \\
\text { staffs, Treasury, } \\
\text { Reserve Bank }\end{array}$ & $\begin{array}{l}\text { National ALP } \\
\text { Conference }\end{array}$ & $\begin{array}{l}\text { National } \\
\text { Taxation } \\
\text { Summit }\end{array}$ \\
\hline $\begin{array}{l}\text { Role of } \\
\text { Cabinet }\end{array}$ & $\begin{array}{l}\text { No formal } \\
\text { role }\end{array}$ & Rubber stamp & No formal role & $\begin{array}{l}\text { Major } \\
\text { preliminary } \\
\text { battleground }\end{array}$ \\
\hline $\begin{array}{l}\text { Political } \\
\text { choice }\end{array}$ & $\begin{array}{l}\text { Adoption of } \\
\text { multilateral } \\
\text { Accord on } \\
\text { economic } \\
\text { recovery and } \\
\text { wage restraint }\end{array}$ & $\begin{array}{l}\text { Decision to } \\
\text { float the } \\
\text { currency and } \\
\text { deregulate } \\
\text { exchange } \\
\text { controls }\end{array}$ & $\begin{array}{l}\text { Decision to } \\
\text { allow for entry } \\
\text { of foreign } \\
\text { banks and } \\
\text { deregulation } \\
\text { of financial } \\
\text { services }\end{array}$ & $\begin{array}{l}\text { Decision } \\
\text { to abandon } \\
\text { government's } \\
\text { option C tax } \\
\text { package }\end{array}$ \\
\hline $\begin{array}{l}\text { Reform } \\
\text { outcome }\end{array}$ & $\begin{array}{l}\text { Sustained } \\
\text { inflation- } \\
\text { reducing wage } \\
\text { restraint, } \\
\text { sustained } \\
\text { government- } \\
\text { ACTU } \\
\text { partnership }\end{array}$ & $\begin{array}{l}\text { Institutional } \\
\text { reconfiguration } \\
\text { of Australian } \\
\text { economy } \\
\text { ("opening up") } \\
\text { and monetary } \\
\text { policy (scope } \\
\text { and } \\
\text { instruments) }\end{array}$ & $\begin{array}{l}\text { Intensified } \\
\text { competition in } \\
\text { the financial } \\
\text { sector, } \\
\text { accompanied } \\
\text { by loose } \\
\text { lending and } \\
\text { investment } \\
\text { practices }\end{array}$ & $\begin{array}{l}\text { Adoption of } \\
\text { modified set } \\
\text { of tax reforms, } \\
\text { not including } \\
\text { consumption } \\
\text { tax }\end{array}$ \\
\hline
\end{tabular}


The instinctive macroeconomic response to crisis, based on historical precedents since the 1930s, was not to pursue internationally orientated reform, but rather to stimulate domestic demand (for recession) and to increase protection and exchange controls (for balance of payments weakness). Government used the crisis atmosphere of 1983 and 1986 to advance the reform effort, but there is no sense in which the shape of the reform program was itself determined by crisis.

While it is also true that ideas were important, these ideas did not fall into policy by themselves; they were taken up, adapted, and championed by policy-makers and policy leaders. Reform was also more than just improvisation in the face of acute crises. Hawke preached the virtues of a consensual approach to policy-making long before entering Parliament, while the Accord-as the institutional foundation for a simultaneous fight against inflation and unemployment-was under negotiation for a number of years before Labor gained office. The decision to float the dollar was obviously a response to a currency crisis induced from outside, yet Hawke and Keating began working towards deregulation of the financial system almost immediately after taking office and finding themselves forced to devalue the currency, while the Reserve Bank was strongly in favor of the float well before any actual crisis.

First and foremost, however, the reforms of the Hawke era were an act of political willpower. They have been called a "heretical act" for a Labor Cabinet to undertake (Emy and Hughes, 9). As John Edwards (1996, 265) concludes, "At the time Hawke and Keating deregulated the Australian financial system, their work was against formal Labor Party policy and opposed by the Left of the party. In the case of the float, it was also opposed by the former Secretary of the Treasury and some (though not all) of his senior subordinates." Moreover, by the content and timing of Labor's choices, Australia became a leader and not a laggard in the reform process. As Edwards $(1996,265)$ argues, "Perhaps it was inevitable some day, in some form, but there was nothing at all inevitable about the shape and timing of the swift and almost complete deregulation of interest rates and the exchange rate, and the increase in the number of banks in Australia in 1983, 1984, and 1985." In fact, many countries with which Australia maintained close economic ties had not adopted these reforms a decade later.

\section{Political Leadership as the Engine of Reform: Assessing the Hypotheses}

The first thing to be observed is the centrality of Hawke and Keating as the political prime movers in the reform process, at least in the four episodes examined here. In all four cases, they were at the heart of the action, collaborating intensely in all cases but the Economic Summit and the early Accord process. The case comparison does betray a shift in the locus of reformist leadership over time, however. Whereas Hawke dominated the Summit preparations both intellectually and procedurally, 
bringing a skeptical, passive Keating along only after the Accord turned out to work, the Accord's subsequent "maintenance" and the initiation of the other three reforms saw a gradual increase in Keating's proactiveness and a more residual, enabling role for Hawke. This was the case with foreign bank entry, and particularly with respect to tax reform, where Keating was the policy zealot, strenuously trying to keep Hawke on board his "tax cart" as he prepared to fight the case in Cabinet, caucus, and country. This shift represented Keating's growing confidence in his portfolio and Hawke's willingness to allow him autonomy in his portfolio.

Having established who performed the political leadership functions, let us now turn to the hypotheses in greater detail.

\section{Hypothesis 1: Crisis Framing}

If the leadership persuades enough parts of its political and social constituencies that continuation of the status quo is not merely unwise but even dangerous, the momentum for reform may well become unstoppable. As we saw earlier, the dramatization of the 1983 budget outlook was sufficient to allow Hawke and Keating to modify Labor's election program and go for spending restrictions. This pattern can also be found in the Economic Summit and dollar-float cases. The Economic Summit initiative was made acceptable by pointing to the economic and political malaise produced by Fraser's "fight inflation first" policies, which had failed to stop inflation-enhancing wage claims and had thoroughly poisoned labor relations. Despite a good deal of bureaucratic opposition from Stone, the floating of the dollar was widely seen by other policy-makers as the only realistic response to the dramatic capital fluctuations Australia was experiencing and the costly and destabilizing currency purchases and sales that the Reserve Bank was being forced to make in order to protect the value of the dollar under the managed exchange-rate system. The events of 8-9 December have all the characteristics of a Kingdonian "policy window." Here was an existing, yet stalemated, policy solution waiting for a big enough problem to come along to provide the final push towards its acceptance. The scenarios were in place, the forward exchange rate had already been floated weeks before, and the Reserve Bank's "war book" was ready to be put into action. The alarming capital-flow figures were exactly the kind of powerful cue the reformist coalition consisting of Hawke, his key advisers, Keating and the Treasury needed to cut themselves loose from Stone and carry the Cabinet for what was essentially a step into the unknown.

In contrast, there was no successful crisis framing in the other two cases. For banking deregulation, such framing was unnecessary, because the reform momentum produced by prior policy reversals (including the float) was big enough to overcome any skepticism. Keating was at a high point in his status as Treasurer. This, combined with his eloquent critique of the existing, essentially oligopolistic Australian banking system, was 
enough to persuade the ALP caucus to go along with the liberalization. That the Martin review group, with members seen as acceptable to the Labor Party, was also promoting the reforms is likely to have made the change of mind somewhat easier. The situation was different in 1985. The existing tax system may have looked bad from a Treasury perspective, but the very fact that it contained so many loopholes and evasion possibilities made it not at all unacceptable to large segments of Australian society. The left of the Labor party and its union supporters were not entirely convinced that a move towards a possibly more regressive consumption tax was in the best interest of its constituents. Keating managed to force the option $C$ package through Cabinet by the sheer force of his persuasive personality, aided by his mastery of the highly technical nature of the subject matter. Yet, despite heroic efforts during his whistlestop tour of the country, Keating did not succeed in convincing the world outside that this was a crisis that needed to be resolved by a step as drastic and symbolically sensitive as the taxation of food and basic consumer goods.

In sum, therefore, the evidence from this study provides modest support for the hypothesis. A stringent interpretation, however, suggests that although crisis framing may indeed be an important aid to reformist leadership, it is not a necessary (see banking case), nor a sufficient (see tax reform case) precondition.

\section{Hypothesis 2: Cohesion and Commitment}

The case evidence suggests that a strong intellectual and political commitment on the part of leadership is a necessary but not a sufficient condition for reform success. The Accord had been developed through several years of negotiation between leading Labor and ACTU officials, and, once elected leader, Hawke became its strong supporter and public champion, with the powerful ACTU and its secretary, Kelty, united strongly behind it. Hawke and Keating were both strongly persuaded of the need to break with the system of managed exchange rates and, in the wake of the float, to take what were maintained to be the next logical steps in financial deregulation, including foreign-bank entry. This commitment to financial deregulation was supported by the central agencies (except Treasury, in the case of the float) and the Reserve Bank and given some legitimacy by the Martin review group. Keating came to want comprehensive tax reform-including a general consumption tax-at least as badly as Hawke had wanted the Economic Summit and the Accord.

In three out of four cases, the leaders' desire for reform was matched by propitious circumstances: the "honeymoon period," during which the victorious Labor leader was allowed a "fair go" by his generally skeptical Labor constituency, as well as by broad strands within the community willing to try a new way of addressing the stagflation problem; the dollar float, in which market forces made the decision nearly inevitable; and the 
banking deregulation, in which the momentum of swift and seemingly successful prior reforms greatly enhanced the leadership's credibility in proposing this further step. In the tax reform case, there were no such auxiliary factors. On the contrary, opposition was almost universal, and even the powerful coalition of Treasurer and Treasury proved unable to carry the full option $\mathrm{C}$ reform package.

The cohesive, albeit mainly functional, bond between Prime Minister and Treasurer was pivotal in seeing these reforms through. Both had broadly similar policy aims and worked together to achieve them. The added value of collegial reformist leadership, compared to individualized leadership, depends partly on the complementarity of individual reformers, since this enhances the performance of the reformist leadership functions identified above. The Hawke-Keating tandem displayed this complementarity. In his comprehensive study of the period, Kelly (55) puts it as follows: "The Hawke-Keating partnership was sealed by mid1983. It was tied by common interest and its strength rested upon two factors-complementary political skills and similar policy instincts. It was never just a two-man government; but it was a government dominated by two men." Elsewhere, he (28) claims that

Hawke and Keating became one of the most successful teams since Federation [of Australia]. They had a policy affinity, an efficient rapport, and complementary political skills. Hawke, unlike Fraser, gave his ministers political room. Keating was dominant within the Cabinet, Hawke within the country. Where Hawke was popular, Keating was dangerous. Hawke preached consensus and Keating wielded the economic knife.

Given their subsequent rivalry, both men have since tended to monopolize the personal responsibility for the 1983-1985 reform successes. But the record shows that credit for the reforms must be shared and that their roles were complementary and mutually reinforcing. Hawke was the public face of the Accord; Keating saw to it that it became an enduring success and instrument of economic policy. Even though, at the time, they were still developing their style of cooperation, they obtained the float together. Keating later delivered banking deregulation and various other reforms, with Hawke concurring and backing him up when needed. While some accounts see Keating as the "stoker of ideas" and Hawke as the public face and chairman, Hawke also had strong economic-policy convictions. Particularly in the first months of the government, economic policy was made as much in the Prime Minister's office and department as it was in the Treasurer's.

The point relevant to this analysis, however, is not the exact nature of the Prime Minister-Treasurer balance of power but the fact that the reforms discussed here were, to a considerable extent, crafted only in these two offices and their attendant bureaucracies, with the ACTU obviously key to the Accord process. While some accounts of the Labor government tend to understate the role of other members of the government in policy reform - and, particularly in the Accord, privatization, micro- 
economic reform, and trade liberalization, there were other important ministers and agencies-Keating and Hawke, working together, made a powerful team. In a number of instances, they reached agreement on policy directions before presenting them to Cabinet.

The tandem worked despite the two members being very different individuals with very different political styles: Hawke, the academically trained yet folksy, popular, crowd-loving, politically pragmatic consensus-builder; Keating, the working-class autodidact with an acquired elitist taste, strong policy views, and a phenomenal yet highly divisive rhetorical ability. Moreover, Hawke's belated entry to the party-political arena after an ACTU career had forced a pause in Keating's advance to the ALP leadership. Keating had been among the last ALP principals to switch allegiance to Hawke in his challenge to the leadership of Bill Hayden, whom Keating liked and respected. Not surprisingly, Hawke, in his first days as Prime Minister, seriously considered dropping Keating, a recent and inexperienced Hayden appointment to the shadow Treasury portfolio, from this vital position in his ministry (Richardson).

In addition to its members making complementary contributions to the reform endeavor, cohesive leadership tandems need to have a certain longevity in order to be effective in more protracted reform trajectories. The Hawke-Keating nexus essentially held until 1990, even though from 1986 onwards there were increasing tensions between the two men. The period between 1983 and 1985 was one of particularly close collaboration almost from the start. Yet, even during this period, the relative position of both players changed gradually. Keating began his term relatively unsure of his ability to master the complex Treasury portfolio, and Hawke acted as a kind of mentor to him in the first months. Keating was also respectful of Treasury Secretary Stone's expertise and his ability to create political problems for a government that went against the Treasury view. The currency-float decision was probably a critical turning point for Keating. It proved he could win out over Stone; it also gained him the respect of senior Treasury and Reserve Bank officials and major political credit through favorable mass media coverage and vocal business support. Keating's expanding influence was facilitated by Hawke's "presidential" style of leadership, which allowed ministers broad autonomy in their portfolios (Edwards 1996, 250; Mills, 206).

In 1984, Keating was elected Finance Minister of the Year by a European financial magazine, a title quickly converted into "The World's Greatest Treasurer" by an elated Keating and his proud "mate" Bob Hawke. In short, beginning as junior partner, Keating quickly developed into equal partner (Edwards 1996, 250). Moreover, starting in the lead-up to the 1984 early election campaign, Hawke was for some time thoroughly distraught and depressed by his younger daughter's serious drug addiction. It was Keating who stepped in, kept the government together, and helped manage the political fallout of Hawke's emotional outbursts in front of the cameras. 
The tax reform episode constituted the first major strain in the team. The government proposal for a sweeping tax reform package, including a new consumption tax, had met with almost universal opposition, causing Hawke to do a deal with the ACTU leadership and kill the package in favor of a more incremental reform. At the press conference immediately after the end of the summit, Keating was minimizing the damage. About the package, he remarked cheekily that "It is a bit like Ben Hur: we have crossed the line with one wheel." About Hawke, he said kind things: "No Treasurer, with the best intentions in the world, can get a reform proposal like this through a Cabinet in this country without the support of the PM. I am pleased to say that in the time I have been treasurer that the support has been unqualified and I appreciate that very much" (ABC). Privately, however, he was infuriated at what he saw as Hawke's lack of spine and his betrayal. It was a shadow of things to come. As Keating later reflected, "That was the first one I put back into memory, the first one I did not forgive him for" (ABC).

Despite these growing tensions, however, the tandem remained intact long after the mutual affection had gone, and it maintained its importance in later policy reform struggles.

\section{Hypothesis 3: Arguing for Reform Superiority}

Getting reforms underway requires more than delegitimizing the institutional status quo (see hypothesis 1 ). We argued above that it also presupposes that leadership successfully presents its alternative policy as inevitable, desirable, and feasible, and any alternative option as inferior to its own (hypothesis 3). Herein lies a crucial explanation of the relative success and failure of the four cases studied here. In the first three reforms, either Hawke or Keating or both tended to make a plausible case for the policy innovations they sought. The Accord process was mainly agreed to on grounds of desirability: it is hard to disagree with a highly popular, newly elected political leader who preaches "reconciliation, recovery, and reconstruction" (Hawke, 14) at a time of bitter division and policy paralysis and who proposes a creative, hitherto untried alternative to break the deadlock. Acceptance of the currency float and banking liberalization was more pragmatic. They were portrayed as largely determined by the dictates of the globalizing economy (situational logic), yet at the same time as perfectly feasible and probably economically beneficial for Australia to follow (instrumental logic). However, on top of that, Hawke and Keating's most important persuasive achievement was that they also convinced their constituencies that these innovations were not anathema to ALP core values and the general interests of Australia at large (normative logic).

All these parameters looked quite different for tax reform. From the outset, it was not widely seen as particularly compelling or urgent. The economy seemed to have picked up, and an investment boom was beginning to take shape. People were putting years of economic stress behind 
them. Why, then, should they suddenly start paying a hefty 10- to 12.5percent GST on everything they bought? It was a hard-even impossible-thing to sell, for any leader. Labor ideology was against it, and Keating faced some formidable opposition from popular Labor figures such as New South Wales Premier Neville Wran, who stressed the symbolically sensitive argument that ordinary workers should not have to pay tax for their bread, milk, and other essentials. Also, Keating's essentially long-term, general-interest arguments were unlikely to persuade sectional organizations, including the farmers, big business, and his allies at the ACTU, who all had the short-term interests and fears of their own constituencies to consider. Moreover, in comparison with the scary depth of the option $\mathrm{C}$ plunge, the moderate option A (originally penned in by the Treasury as a token alternative) did not look so bad at all. And, as would be predicted by incrementalist theory, it was ultimately a modified version of option A that Keating managed to salvage from the wreck of the Tax Summit-albeit after fierce and divisive discussion within the full Ministry and lacking Hawke's support during its crucial stages.

\section{Hypothesis 4: Implementation Support}

This hypothesis also receives support from the case studies. For a student of policy-making, steeped in theories of bureaucratic politics and implementation as political game-playing, the most remarkable aspect of the reform episodes described here is the extraordinarily strong links that developed between the political leadership and vital parts of the executive, especially Treasury and the semi-independent Federal Reserve Bank (Gruen and Grattan, 51-56). Once the battle over the float was over, bureau-political infighting was down to a minimum, although there were occasional disagreements (see also Campbell and Halligan).

Both Hawke and, particularly, Keating have been accused by critics of having been co-opted by central agency bureaucrats and the Reserve Bank brass into a neoconservative economic doctrine (Pusey). It is hard to establish cause and effect in retrospect, but there can be no doubt that there was a broad and deep politico-bureaucratic consensus between these actors that, by virtue of Hawke's and Keating's political dominance, became a powerful coalition, advocating fiscal frugality and marketoriented microeconomic reforms. With these and other vital agencies such as the Tax Office on board, bureaucratic implementation was never a big worry. And as far as the float and banking deregulation were concerned, implementation was exclusively a bureaucratic affair.

The cases where implementation support did not depend merely on bureaucratic loyalty and expertise were more unsettled and required more leadership efforts. While not always enthusiastic about the Accord, the central agencies and the line departments had little role in its development and faithfully implemented those parts for which they were responsible. The expectation was, however, that the ACTU would be 
unable to withstand grass-roots pressures for major wage increases at the next wage-determination round. There was widespread speculation that the Accord, the centerpiece of the National Economic Summit, would not survive. However, like Hawke and Keating, Kelty, and Crean, the other union leaders had learned from Whitlam's previous Labor government that a labor movement divided amongst itself could expect only a short time in office. They were determined to do their part to keep this new Labor government in power for much longer. Having former ACTU boss Hawke as Prime Minister virtually ensured that the unions would be influential and fairly treated. The Accord became a spectacular implementation success (although its economic and social consequences have been severely criticized; see, e.g., Bell), yet remained labor-intensive. It was renewed eight times, right up to the end of Labor's period in government in 1996, usually with Keating in the key role on the government side. The Accord proved able to absorb all kinds of economic shocks and setbacks when the economy turned in 1986 and beyond. The increasingly close Keating-Kelty relationship would prove to be vital in achieving this outcome. Compared to the government-union partnership, relations with organized business in Australia were less intense, but key figures enjoyed impeccable access to the top leadership, and a number of business associations and business leaders did not obstruct the reform program-in fact, they welcomed key elements of it.

Again, the tax reform case provides the exception. There were divisions within the bureaucracy, and societal resistance was almost total. The lack of public - particularly ACTU—support became the crucial reason for the failure of option C, and not merely because Hawke had pledged to have tax reform by consensus. The unanimously negative reception of the package would have made implementation exceedingly difficult and might possibly have legitimized systematic evasion and subversion-the very phenomena the new package was supposed to eliminate. There were also the possible electoral costs and the straining of relationships between the ACTU, the extraparlimentary party, and other interest groups. The modified package that Keating forced through the Cabinet in September was not popular either, but it did not worry and infuriate people in the same way that option $\mathrm{C}$ had done.

\section{Hypothesis 5: Control over Decision-Making}

Upon assuming his post, Hawke inherited a Cabinet structure that was conducive to discipline and esprit de corps. The balanced composition of the Cabinet in relation to the full ministry, the formalization of the factions system, the importance of the ERC, and Hawke's expert management of Cabinet meetings all combined to create a fairly well-organized system of collective decision-making (Weller 1990). This was partly made possible by the strong determination on the part of Hawke and other ALP leaders not to repeat the mistakes of the Whitlam Labor government 
(1972-1975), which had been beset by a lack of budgetary discipline and by bitter infighting. Especially in the first Hawke government, a degree of centralization of authority in the ministry was therefore accepted as a necessary price for preventing chaos. This created an opportunity for Cabinet leadership that first Hawke and later Keating exploited to maximum extent. The ERC was important in this process. Especially in the period studied here, the ERC was a fairly close-knit inner circle consisting of ministers with an "economist" outlook. Spending departments were excluded, making it easier to reach consensus on the fundamentals of the government's economic strategy and the making of sizable cuts in budget outlays. While Cabinet structures potentially gave the Prime Minister, as chairman, extensive powers, it was not Hawke's style to impose his views on unwilling colleagues. Instead, as a fellow Labor Cabinet minister noted, Hawke's style

was very much an approach of talking issues through and not to impose a view on controversial issues. That wasn't universally the case ... but his style was more generally to let discussion run. Sometimes he hadn't made up his own mind. He would sum up what the majority position was. It wasn't always what I would have thought the majority position was. (Goldfinch 2000, 259)

On the surface, the evidence of the four cases is mixed. We have two typical examples of a closed style, with Hawke and Keating in full control of both the structure and the process of decision-making. In the dollarfloat case, there was a six-month pre-crisis gestation period in which the locus of the reform battle did not lie within the Cabinet but in ad hoc meetings between Hawke and his staff, Keating and his staff, and the central agency and Reserve Bank elites. The main fight was bureaupolitical: Treasury versus Reserve Bank. Hawke and Keating faced the delicate task of ensuring a Reserve Bank victory without antagonizing Treasury in general and Stone in particular. Treasury animosity had largely debilitated fiscal policy in the Fraser government, and this was another precedent that Hawke and Keating sought to avoid. With Keating being a novice to the portfolio, and at the time nowhere near as confident as he would be from 1984 onwards, going against an authority such as Stone was a major hurdle. The December crisis tilted the balance, as did the increasing signs that significant parts of the Treasury elite supported Keating and not Stone on the issue of currency reform. At the Cabinet level, the decision was rushed through on 9 December, after Keating had prearranged the support of a number of key ministers. It all went so fast, and the subject matter was so complex, that many ministers did not initially understand the magnitude of the decision.

The other example of closed decision-making is banking reform. This was done largely outside the Cabinet in the Keating-Treasury-Reserve Bank nexus and presented to the Cabinet by Hawke and Keating as a fait accompli. The crucial test for the policy was at the Labor party conference, where the prestige of the government weighed in heavily, reinforced 
by Keating's rhetorical talent for framing the discussion and dominating it throughout. This change of policy direction was also given some legitimacy by the Martin review group. Sufficient numbers of agnostics and skeptics were brought on board to carry the conference with broad support.

In the other two cases, there seems to have been a much lower extent of leadership control over the decision-making process, since both involved the unusual institution of a broad-based national summit meeting, a form of ad hoc corporatism (see Bell). Yet this betrays a fundamental difference between these two summits. The National Economic Summit of 1983 was carefully planned and orchestrated by Hawke and his staff, well-timed to coincide with the start of the government and to constitute a symbolic departure from the past. The participating organizations and individuals were virtually handpicked by Hawke, as was the venue: the venerable House Chamber of the Parliament, a symbol for the national importance of this endeavor. Hawke correctly speculated that the very act of bringing together representatives from organizations that were routinely vilifying each other in public constituted a goodwillcreating breakthrough in and of itself. He engineered an aura of national effort and consensus that became so strong that nobody wanted to be responsible for shattering it by falling back into confrontationalism. To some extent, those that might have not backed the new policy directions-particularly the Accord-were outmaneuvered by the well-orchestrated summit. Further accords were negotiated at the highest level between such senior ministers as Willis and Keating and their ministerial staffs and ACTU Secretary Kelty and other ACTU officials. Both groups had a strong interest in maintaining the Accord relationship.

The origins of the Tax Summit were more mundane, and the consensus momentum was virtually absent. The Tax Summit had arisen as an improvisation during the late-1984 election campaign. In a campaign radio interview, Hawke struggled to keep tax reform alive as a policy issue without having to take a substantive position on it, for fear of antagonizing voters. The summit analogy came in handy: he had pulled it off in 1983, so why not do it again in 1985? Yet tax is not the same as a broadbased deal between government and trade unions. Tax reform entails redistribution, a type of policy intervention known to be more controversial than distributive and symbolic policies, under which interest groups do not have to fear the size of their share of the collective purse as much. To swing the natural bias of pocketbook logic and rent-seeking behavior that exists against such reform towards support-or at least acquiescence-is exceedingly hard to achieve, particularly if one insists on doing it by consensus, as Hawke had pledged. Keating, who had not been consulted by Hawke beforehand on the tax summit idea, did not like it at all. Yet since the government had been committed to it, he decided to go all out to obtain his preferred outcome. Cabinet had to be swung, and Keating had to invest massive political capital in doing so, in 
the face of a noncommittal Hawke and open opposition from heavyweights such as Finance Minister Peter Walsh, thereby virtually destroying the norm of consensus so vital to the summit as a policy-making platform. The message of the marathon Cabinet discussion that it was apparently okay to disagree with the government proposal, and this is exactly what all the speakers at the Tax Summit eventually did, was begun by an unexpected and devastating critique from what Keating had figured would be a strong reform proponent-the Business Council of Australia. It became clear that Hawke the electioneering politician may have been successful in neutralizing the tax issue by proposing a summit, but that in doing so, he caused Keating the policy-maker to lose control over the structure and the process of tax reform deliberation and choice.

The tentative conclusion is that the case evidence supports the hypothesis. Structural and process control over decision-making by the leadership were high in all of the three reform successes-in different ways-whereas they were problematic in the case of reform defeat.

\section{CONCLUSIONS}

We have argued in this article that major policy changes and institutional reforms are not a self-evident result of tensions between the challenges emanating from changing environments and the inability of existing policies and institutions to meet these challenges. Environments can be conducive to reform, but they cannot produce it autonomously. Even in an environment as dominant and dynamic as the global international monetary and financial system of the eighties, individual countries adapted their fiscal, monetary, and microeconomic policies and institutions in different ways, to different degrees, and at different times. We argue that political reform craft should be part of the equation in analyzing institutional reforms, and that political leadership lies at the heart of this reform craft. We have presented an analytical framework conceiving of institutional reforms as outcomes of political struggles between reform opponents and proponents. Elaborating Jean Blondel's notion of reformist political leadership, we have subsequently explored how key actors in a policy system can initiate reform struggles and seek to maximize the chances that their preferred reforms will prevail. Finally, we have asserted that reformist political leadership may be exercised more effectively by tandems or collectivities of reform proponents than by individuals.

Reformist political leadership begins with a political judgment that routine adaptation is no longer sufficient to reduce contextual pressures for major changes of policy and/or the institutions by which policies are made. Having set off on the path of reform, the essence of reformist leadership lies in persuading a sufficiently broad spectrum of stakeholders of two things: (1) major changes to the status quo are not only necessary, but urgently required; (2) the specific set of changes proposed by the leaders is not only inherently desirable and practically feasible, but also superior 
to any competing proposals. We have preliminarily tested five hypotheses derived from these general thoughts against the evidence of four reform struggles (three successful, one not) in Australian economic policy during the first three years of the Hawke government (1983-1985). By and large, the case evidence confirms the plausibility of the claims made.

This cannot be more than a first indication that there is a potentially useful track here in bringing people and politics back to the analysis of institutional reform. The analysis presented here has its limitations. First of all, rather than examining all possible contextual and actor variables, we have focused on the role of reformist political leadership and its impact upon reform struggles and reform outcomes. Secondly, we have confined our empirical work to one country and one policy arena within it. Thus, the impact of variations in the institutional structure-systemic or sectoral - of policy-making on the nature and effectiveness of reformist political leadership could not be ascertained. The Australian political system has predominantly Westminster, majoritarian traits, although it possesses a powerful upper house of review in the Senate and has the added complication of a federal system. It may well be that Westminster systems are more conducive to nonincremental reforms, because of their ability to produce major political pendulum swings in government, although, in many cases, federal structures encourage and sometimes force a degree of compromise and negotiation in policy change (although, see Rose and Davies). In consensual systems with proportional representation and coalition or minority government, there may be a stronger tendency towards "mutual adjustment" and incrementalism. The nature and role of reformist leadership may, therefore, be qualitatively different from the picture that emerges from an examination of Australian-or, indeed, British (see Moon) - cases. In fact, reformist leadership in consensual democracies may be more geared towards the ability to foster continuous, unspectacular "policy learning" in the face of changing circumstances (see, for example, Visser and Hemerijck). Therefore, it is up to future comparative studies to establish the scope and range of validity of the theory presented here.

\section{NOTES}

1. The Treasury, the Department of Finance, and the Department of Prime Minister and Cabinet are collectively known as the central agencies.

2. The Economic Planning and Advisory Council-set up in 1983 and including representation from business, unions, social-service organizations, and state politicians, and with its own research and support staff-was another (Singleton 1995).

\section{REFERENCES}

ABC Television. 1993. Labor in Power. Six-hour television documentary series. Produced and directed by Sue Spencer. 
Aberbach, J. D., and T. Christensen. 2001. Radical Reform in New Zealand: Crisis, Windows of Opportunity, and Rational Actors. Public Administration 79:403-422.

Andeweg, R. B. 1993. A Model of the Cabinet System: The Dimension of the Decision-Making Process. In J. Blondel and F. Müller-Rommel, eds., Governing Together. London: Macmillan.

Bardach, E. 1983. The Implementation Game. Cambridge, MA: Harvard University Press.

Barnett, Pauline, and Kerry Jacobs. 2000. Policy-Making in a Restructured State: The Case of the 1991 Health Reform Policy in New Zealand. Australian Journal of Public Administration 59:73-86.

Baumgartner, F. R., and B. D. Jones. 1993. Agendas and Instability in American Politics. Chicago: University of Chicago Press.

Baylis, J. 1989. Governing by Committee. Albany: State University of New York Press.

Bell, S. 1997. Ungoverning the Economy: The Political Economy of Australian Economic Policy. Melbourne: Oxford University Press.

Blondel, J. 1987. Political Leadership: A General Analysis. London: Sage.

Boin, R. A., and M. H. P. Otten. 1996. Beyond the Crisis Window for Reform: Some Ramifications for Implementation. Journal of Contingencies and Crisis Management 4:149-161.

Bostdorff, D. M. 1994. The Presidency and the Rhetoric of Foreign Crisis. Columbia: University of South Carolina Press.

Boston, Jonathon. 1994. Grand Designs and Unpleasant Realities: The Fate of the National Government's Proposals for the Integrated Targeting of Social Assistance. Political Science 46:1-21.

Brewer, G., and P. Deleon. 1983. The Foundations of Policy Analysis. Homewood, IL: Dorsey Press.

Bryson, J. W., and B. Corsby. 1992. Leadership for the Common Good. San Francisco: Jossey-Bass.

Burns, J. M. 1978. Leadership. New York: Harper and Row.

Campbell, C., and J. Halligan. 1992. Political Leadership in an Age of Constraint: Bureaucratic Politics under Hawke and Keating. St. Leonards: Allen and Unwin.

Carew, E. 1988. Keating: A Biography. Sydney: Allen and Unwin.

Douglas, R. 1993. Unfinished Business. Auckland: Random House.

Dror, Y. 1986. Policy-Making under Adversity. New Brunswick: Transaction.

Dunleavy, P., and R. Rhodes, eds. 1995. Prime Minister, Cabinet and Core Executive. London: Macmillan.

Edelman, M. 1971. Politics as Symbolic Action. Chicago: Markham. 1977. Political Language. New York: Academic Press.

Edwards, J. 1996. Keating: The Inside Story. Ringwood: Penguin.

Elgie, R. 1995. Political Leadership in Liberal Democracies. London: Macmillan.

Emy, H. V. 1993. Remaking Australia: The State, the Market and Australia's Future. St. Leonards: Allen and Unwin.

Emy, H. V., and O. E. Hughes. 1991. Australian Politics: Realities in Conflict. South Melbourne: Macmillan.

Garnaut, Ross. 1994. Australia. In J. Williamson, ed., The Political Economy of Policy Reform. Washington, DC: Institute for International Economics.

Garrett, G., and P. Lange. 1995. Internationalization, Institutions, and Policy Change. International Organization 49:627-655.

George, A. L., and J. L. George. 1962. Woodrow Wilson and Colonel House: A Personality Study. New York: Dover.

Goldfinch, Shaun. 1998. Remaking New Zealand's Economic Policy: Institutional Elites as Radical Innovators, 1984-93. Governance 11:177-207. 
2000. Remaking New Zealand and Australian Economic Policy: Ideas, Institutions, and Policy Communities. Washington, DC: Georgetown University Press.

Goodin, R. E. 1982. Political Theory and Public Policy. Cambridge, UK: Cambridge University Press.

Gruen, F., and M. Grattan. 1993. Managing Government: Labor's Achievements and Failures. Melbourne: Longman Cheshire.

Hall, P. 1993. Policy Paradigms, Social Learning and the State: The Case of Economic Policy-Making in Britain. Comparative Politics 25:275-296.

Hargrove, E. C. 1989. Two Conceptions of Institutional Leadership. In B. Jones, ed., Leadership and Politics. Lawrence: University of Kansas Press.

Harper, I. R., and P. J. Leslie. 1993. The Case of Financial Deregulation: "Economic Rationalism" on Trial. In S. King and P. Lloyd, eds., Economic Rationalism: Dead End or Way Forward? St. Leonards: Allen and Unwin.

Hart, Paul 't. 1994. Groupthink in Government. Baltimore: Johns Hopkins University Press.

Hawke, B. 1984. National Reconciliation: The Speeches of Bob Hawke. Sydney: Fontana.

- 1996. The Hawke Memoirs. Port Melbourne: Reed.

Hermann, C. F. 1989. Changing Course: When Governments Choose to Redirect Foreign Policy. International Studies Quarterly 34:3-21.

Hesse, J. J., and A. Benz. 1993. Modernisierung der Staatsorganisation. [Public Sector Modernization]. Baden-Baden: Nomos.

Hesse, J. J., and N. Johnson, eds. 1995. Constitutional Change and Policy in Europe. Oxford: Oxford University Press.

Hirschman, A. O. 1991. The Rhetoric of Reaction. Cambridge, MA: Belknap Press, Harvard University Press.

Hogwood, B., and B. G. Peters. 1983. Policy Dynamics. Brighton: Wheatsheaf.

House, R. J. 1977. A 1976 Theory of Charismatic Leadership. In J. G. Hunt and L. L. Larson, eds., Leadership: The Cutting Edge. Carbondale: Southern Illinois University Press.

Hoyt, P. D., and J. A. Garrison. 1997. Political Manipulations within a Small Group: Foreign Policy Advisors in the Carter Administration. In P. 't Hart, E. K. Stern, and B. Sundelius, eds., Beyond Groupthink. Ann Arbor: University of Michigan Press.

James, S. 1991. The British Cabinet. London: Routledge.

Janis, I. L., and L. Mann. 1977. Decision-Making. New York: Free Press.

Kaarbo, J., and M. G. Hermann. 1998. Leadership Styles of Prime Ministers: How Individual Differences Affect the Foreign Policy-Making Process. Leadership Quarterly 9:243-263.

Keating, P. 1996. Paul Keating's Account of the Decision to Float. In J. Edwards, ed., Keating: The Inside Story. Ringwood: Penguin.

Keeler, J. T. S. 1993. Opening the Window for Reform: Mandates, Crisis, and Extraordinary Policy-Making. Comparative Political Studies 25:433-486.

Kelly, P. 1992. The End of Certainty: Power, Politics and Business in Australia. St. Leonards: Allen and Unwin.

Kingdon, J. W. 1984. Agendas, Alternatives, and Public Policy. Boston: Little, Brown.

Klein, K. J., and R. J. House. 1995. On Fire: Charismatic Leadership and Levels of Analysis. Leadership Quarterly 6:183-198.

Lindblom, C. E. 1979. Still Muddling: Not Yet Through. Public Administration Review 39:517-526.

Lynn, L. E. 1987. Managing Public Policy. Chicago: University of Chicago Press.

Maoz, Z. 1990. Framing the National Interest: The Manipulation of Foreign Policy Decisions in Group Settings. World Politics 43:77-111.

March, J. G. 1994. How Decisions Happen. New York: Free Press. 
Marmor, T. R., and P. Fellman. 1986. Policy Entrepreneurship in Government: An American Study. Journal of Public Policy 6:225-254.

McFaul, M. 1995. State Power, Institutional Change and the Politics of Privatization in Russia. World Politics 47:210-243.

Mills, S. 1993. The Hawke Years: The Story from the Inside. Ringwood: Penguin.

Mintrom, M., and S. Vergari. 1996. Advocacy Coalitions, Policy Entrepreneurs, and Policy Change. Policy Studies Journal 24:420-438.

Moon, J. 1995. Innovative Leadership and Policy Change: Lessons from Thatcher. Governance 8:1-25.

Mucciaroni, G. 1992. The Garbage Can Model and the Study of Policy-Making: A Critique. Polity 24:459-482.

Neustadt, R. E. 1960. Presidential Power. New York: Wiley.

Newmann, W. W. 1998. Foreign Policy Decision-Making, Garbage Cans, and Policy Shifts: The Eisenhower Administration and the "Chances for Peace" Speech. American Review of Public Administration 28:187-212.

Olsen, J. P., and B. G. Peters, eds. 1996. Learning from Experience. Oslo: Scandinavian University Press.

Peters, B. G., J. J. Hesse, and C. C. Hood. 1999. Paradoxes in Public Sector Reform. Berlin: Duncker and Humblot.

Polsby, N. 1984. Political Innovation in America. New Haven, CT: Yale University Press.

Pusey, M. 1991. Economic Rationalism in Canberra: A Nation-Building State Changes Its Mind. Cambridge, UK: Cambridge University Press.

Rhodes, R. A. W. 1997. "Shackling the Leader?": Coherence, Capacity and the Hollow Crown. In P. Weller, H. Bakvis, and R. A. W. Rhodes, eds., The Hollow Crown: Countervailing Trends in Core Executives. London: Macmillan.

Richardson, G. 1994. Whatever It Takes. Moorbank: Bantam.

Rose, R., and J. Davies. 1994. Inheritance in Public Policy. New Haven, CT: Yale University Press.

Singleton, G. 1990. The Accord and the Australian Labor Movement. Carlton: Melbourne University Press.

-1995. Trial by Westminster: The Fate of Economic Advisory Councils in the United States and Australia. Journal of Commonwealth and Comparative Politics 33:240-256.

Stern, E., and B. Verbeek. 1999. Whither the Study of Governmental Politics in Foreign Policy-Making? A Symposium. Mershon International Studies Review 42:205-255.

Suchman, M. C. 1995. Managing Legitimacy: Strategic and Institutional Approaches. Academy of Management Review 20:571-610.

van Dooren, R. 1994. Messengers from the Promised Land: An Interactive Theory of Political Charisma. Leiden: DSWO Press.

Vertzberger, Y. Y. I. 1998. Risk Taking and Decisionmaking. Stanford: Stanford University Press.

Visser, J., and A. C. Hemerijck. 1997. A Dutch Miracle. Amsterdam: Amsterdam University Press.

Wallis, J. 1997. Conspiracy and the Policy Process: A Case Study of the New Zealand Experience. Journal of Public Policy 17:1-29.

Wallis, J., and B. Dollery. 1999. Market Failure, Government Failure, Leadership and Public Policy. Houndmills, Basingstoke: Macmillan.

Walsh, P. 1995. Confessions of a Failed Finance Minister. Sydney: Random House.

Weller, P. 1985. First among Equals: Prime Ministers in Westminster Systems. Sydney: Allen and Unwin.

1990. Cabinet and Prime Minister. In J. Summers, D. Woodward, and A. Parkin, eds., Government, Politics and Power in Australia. 4th ed. Melbourne: Longman Chesire. 
Williamson, J. 1994a. In Search of a Manual for Technopols. In J. Williamson, ed., The Political Economy of Policy Reform. Washington, DC: Institute for International Economics.

Williamson, J., ed. 1994b. The Political Economy of Policy Reform. Washington, DC: Institute for International Economics.

Young, H. 1989. The Iron Lady: A Biography of Margaret Thatcher. New York: Noonday Press. 